\title{
Endometrial thickness by USG as a guideline for the treatment of dysfunctional uterine bleeding in Premenopausal women
}

\author{
Shinde $\mathbf{C D}^{1}$, Patil PG ${ }^{2}$, Mane $\mathbf{R}^{3}$ \\ ${ }^{1}$ Dr. Charushila D. Shinde, MD (Anatomy), Assistant Professor, ${ }^{2}$ Dr. Pankaj G. Patil, MD (Obstetric \& Gynecology), \\ Associate Professor, ${ }^{3}$ Dr. Rekha Mane, MD (Anatomy), Assistant Professor. All are affiliated to MGM Medical College, \\ kamothe Navi Mumbai, Maharashtra, India
}

Address for correspondence: Dr Charushilla D Shinde, Email: charushila29@gmail.com

\begin{abstract}
Introduction: Endometrium is mucosal layer of uterus. Throughout the reproductive age, endometrium undergoes cyclical changes during each lunar month to prepare uterus for implantation. Dysfunctional uterine bleeding (DUB) is the most common cause of abnormal vaginal bleeding (AUB) during a womans reproductive years. It affects womens health both medically and socially. Aim \& Objective: To decide cut of limit of Endometrial thickness (ET) by ultrasonography (USG) for the treatment of DUB patients in premenopausal women. Method: A total of 60 patients with irregular menstrual bleeding of DUB attending Department of Obstetric and Gynecology in M G M Medical College and Hospital were selected. ET was noted by USG. Result: In younger age group most of patients showed good response to medical line of treatment, while premenopausal women needed surgical line of treatment. Conclusion: ET in younger age group is in the normal range $(<8 \mathrm{~mm})$ as compared to moderate ET $(8-11 \mathrm{~mm})$ in perimenopausal women. In perimenopausal age, the preferred line of treatment will be either D\&C or hysterectomy, when ET is $>8 \mathrm{~mm}$.
\end{abstract}

Key words: Ultrasonography, Endometrium, Dysfunctional Uterine Bleeding, Endometrial thickness, Premenopausal women.

\section{Introduction}

Newer tools are available to study human anatomy in more details such as MRI, CT scan, Color Doppler, PET scan, USG, X-ray etc. Nowadays ultra-sonography is used extensively and accepted as a safe, non-invasive modality to evaluate female reproductive system. In this study we have tried to measure endometrial thickness irregular menstrual cycle (Abnormal uterine bleeding) to decide the modality of treatment to patients.

Endometrium is mucosal layer of uterus. Throughout the reproductive age, endometrium undergoes cyclical changes during each lunar month to prepare uterus for implantation. Endometrium proliferates and regenerates during menstrual cycle [1].

Dysfunctional uterine bleeding is the most common cause of abnormal vaginal bleeding during a woman's reproductive years. Dysfunctional uterine bleeding

Manuscript received: $22^{\text {nd }} \mathrm{Feb} 2015$

Reviewed: $27^{\text {th }}$ Feb 2015

Author Corrected: $14^{\text {th }}$ Mar 2015

Accepted for Publication: $29^{\text {th }}$ Mar 2015
(DUB) is defined as abnormal uterine bleeding in the absence of organic cause and is mainly due to changes in hormone levels. It affects women's health both medically and socially [2].

Present study is focused on:

a) Measuring Endometrial thickness (ET) during irregular/abnormal menstrual cycles

b) Effect of hormonal treatment on ET in different menstrual disorders.

c) To decide the line of treatment (t/t) in premenopausal age group \& cut of limit

d) Try to determine cut off limits in patients of abnormal uterine bleeding in premenopausal women so as plan for medical or surgical line of treatment with reference to ET, by ultrasonography.

\section{Material and Method}

- 60 patients of DUB attending of Obstetric and Gynecology in M G M Medical College and Hospital were selected.

- Patients are divided into different age group- eg. Less than 25 yr, 25-28 yr, 29-32 yr, 33-36 yr etc. 
- Patients more than 33 yrs of age considered as premenopausal women.

- A detailed menstrual history was taken from the subjects included in study after informed consent.

- Day of Menstrual cycle (if possible) and ET by ultrasonography were noted.
- After giving treatment to the patients for irregular non cyclical bleeding, the sonography was repeated after finishing the course of treatment again ET was noted.

- $\quad$ ET more than $11 \mathrm{~mm}$ advised for Histopathalogical examination.

\section{Result}

Total 60 patients of different age group, having irregular menstrual cycles were observed to study endometrial thickness, response of patient to medical line of $\mathrm{t} / \mathrm{t}$. The results were tabulated.

Table 1: Showing relation of Endometrial thickness \& line of treatment in different age group

\begin{tabular}{|c|c|c|c|c|c|c|}
\hline \multirow[b]{2}{*}{$\begin{array}{l}\text { Age group } \\
(\mathbf{y r})\end{array}$} & \multirow[b]{2}{*}{$\begin{array}{l}\text { Total No. } \\
\text { of patients }\end{array}$} & \multirow[b]{2}{*}{$\begin{array}{l}\text { Average } \\
\text { ET }(\mathbf{m m})\end{array}$} & \multirow[b]{2}{*}{$\begin{array}{l}\text { ET } \\
(\mathbf{m m})\end{array}$} & \multirow[b]{2}{*}{$\begin{array}{l}\text { No. } \\
\text { of patients }\end{array}$} & \multicolumn{2}{|l|}{ Treatment } \\
\hline & & & & & $\begin{array}{l}\text { Medical } \\
\%, \text { (No.of } \\
\text { patient) }\end{array}$ & $\begin{array}{l}\text { Surgical } \\
(\%)(\text { No.of } \\
\text { patient) }\end{array}$ \\
\hline \multirow[t]{4}{*}{$<25$} & \multirow[t]{3}{*}{4} & \multirow[t]{3}{*}{6.9} & $<8$ & 3 & $67(2)$ & $33(1)$ \\
\hline & & & $8-11$ & 1 & 100(1) & - \\
\hline & & & $>11$ & 0 & - & - \\
\hline & 4 & & & & $75(3)$ & $25(1)$ \\
\hline \multirow[t]{4}{*}{$25-28$} & \multirow[t]{3}{*}{13} & \multirow[t]{3}{*}{6.5} & $<8$ & 10 & $100(10)$ & - \\
\hline & & & $8-11$ & 3 & $100(3)$ & - \\
\hline & & & $>11$ & 0 & - & - \\
\hline & 13 & & & & $100(13)$ & - \\
\hline \multirow[t]{4}{*}{$29-32$} & \multirow[t]{3}{*}{13} & \multirow[t]{3}{*}{6.9} & $<8$ & 11 & $82(9)$ & $18(2)$ \\
\hline & & & $8-11$ & 2 & $100(2)$ & - \\
\hline & & & $>11$ & 0 & - & - \\
\hline & 13 & & & & $84.6(11)$ & $13.4(2)$ \\
\hline \multirow[t]{4}{*}{$33-36$} & \multirow[t]{3}{*}{10} & \multirow[t]{3}{*}{9.5} & $<8$ & 4 & $100(4)$ & - \\
\hline & & & $8-11$ & 4 & $25(1)$ & $75(3)$ \\
\hline & & & $>11$ & 2 & - & $100(2)$ \\
\hline & 8 & & & & $50(5)$ & $50(5)$ \\
\hline \multirow[t]{4}{*}{$37-40$} & \multirow[t]{3}{*}{12} & \multirow[t]{3}{*}{9.4} & $<8$ & 2 & $50(1)$ & $50(1)$ \\
\hline & & & $8-11$ & 8 & $50(4)$ & $50(4)$ \\
\hline & & & $>11$ & 2 & $50(1)$ & $50(1)$ \\
\hline & 12 & & & & $50(6)$ & $50(6)$ \\
\hline \multirow[t]{4}{*}{$41-44$} & \multirow[t]{3}{*}{6} & \multirow[t]{3}{*}{10.6} & $<8$ & 2 & - & $100(2)$ \\
\hline & & & $8-11$ & 1 & - & $100(1)$ \\
\hline & & & $>11$ & 3 & - & $100(3)$ \\
\hline & 6 & & & & - & $100(6)$ \\
\hline \multirow[t]{4}{*}{$>44$} & \multirow[t]{3}{*}{2} & \multirow[t]{3}{*}{13} & $<8$ & - & - & - \\
\hline & & & $8-11$ & - & - & - \\
\hline & & & $>11$ & 2 & - & $100(2)$ \\
\hline & 2 & & & & - & $100(2)$ \\
\hline
\end{tabular}

Total 60 patients of AUB were observed. Normal ET (up to $8 \mathrm{~mm}$ ) was seen in 37 patients (61.6\%), mild to moderate $\mathrm{ET}(8.1$ to $11 \mathrm{~mm})$ was seen in 14 patients $(23.4 \%)$ and severe increase in thickness (>than $11 \mathrm{~mm})$ was seen in 9 patients $(15 \%)$. 
Table 2: Showing response of patient to treatment in premenopausal age group

\begin{tabular}{|c|c|c|c|c|c|c|c|}
\hline \multirow{4}{*}{$\begin{array}{l}\text { Premenopausal } \\
\text { Women age gr. }\end{array}$} & \multirow{4}{*}{$\begin{array}{l}\text { Total No. of } \\
\text { patients }\end{array}$} & \multicolumn{6}{|c|}{ Response to treatment } \\
\hline & & \multicolumn{2}{|l|}{ Medical } & \multicolumn{4}{|c|}{ Surgical } \\
\hline & & \multirow[t]{2}{*}{$\begin{array}{ll}\text { No. } & \text { of } \\
\text { patients } & \end{array}$} & \multirow[t]{2}{*}{$\%$} & \multicolumn{2}{|l|}{$\mathrm{D} \& \mathrm{C}$} & \multicolumn{2}{|c|}{$\begin{array}{l}\text { Hysterectomy } \\
\text { Advised }\end{array}$} \\
\hline & & & & $\begin{array}{l}\text { No. of } \\
\text { patients }\end{array}$ & $\%$ & $\begin{array}{l}\text { No. of } \\
\text { Patients }\end{array}$ & $\%$ \\
\hline $33-46 \mathrm{yr}$ & 30 & 10 & 33.3 & 13 & 43.4 & 7 & 23.3 \\
\hline
\end{tabular}

Most of the patients had DUB pattern of per vaginal bleeding. There was significant decrease in ET in DUB patients after medical line of $t / t$ in different patterns of bleeding.

- In age group less than $25 \mathrm{yr}, 75 \%$ patient having normal ET responded to medical line of treatment while $25 \%$ were advised for surgical line of treatment.

- In 25-28 yr of age group $100 \%$ responded well to medical line of treatment.

- $\quad$ In $3^{\text {rd }}$ group of $29-32 \mathrm{yr}, 82 \%$ patient having ET upto $8 \mathrm{~mm} \& 100 \%$ patients ET $8-11 \mathrm{~mm}$ responded to medical treatment.

- 10 patients were observed in age group of 33-36 yr. Their average ET was $9.5 \mathrm{~mm}$. Out of which $50 \%$ were required surgical t/t (D \& C/ Hysterectomy)

- $50 \%$ patients were cured by medical line of $t / t$ in age group of 37-40 yr. 12 patients were observed in this group.

- In age group $41-44 \mathrm{yr} \&$ greater than $44 \mathrm{yr}, 100 \%$ patients were advised for surgical line of $t / t$. Their average ET was $10.6 \mathrm{~mm}$. Here it shows that once increase in thickness less likely to respond with medical therapy with increase in age group.

\section{Discussion}

Measurement of ET with ultrasonography is commonly used nowadays. Its clinical importance and application extended throughout the phases of the reproductive lives of women.

Persadie RJ, in 2002 reviewed the ultrasonographic assessment of ET. ET can vary with the Menstrual cycle and with the use of hormone replacement therapy or selective estrogen receptor modulators [3].

Ultrasonography is an excellent non-invasive tool to diagnose anatomic cause of DUB. A study by de Vries et al in 2010, recommends evaluation of ET by TVS as an initial approach for premenopausal patients with DUB [4].
Chittacharoen A et al in 2002 evaluated the value of sonohysterography in diagnosis of patients with AUB. And they concluded that Sonohysterography is a highly sensitive, specific, and accurate screening procedure for the evaluation of uterine cavity in AUB and is a simple, minimally invasive and effective tool to use in the evaluation of patients [5].

Abnormal vaginal bleeding is one of the most common presenting complaints in women regardless of age. This complaint is taken more seriously in women of late reproductive age due to some possible malignant cause, but majority of women with irregular and excessive bleeding have benign disorders. The most frequently used diagnostic investigation is TVS [6].

Abnormal and excessive endometrial bleeding without structural pathology occurs in reproductive women but is more common in adolescent and perimenopausal women. In perimenopausal women menstrual cycles often become more irregular due to decreased number of ovarian follicles and their increased resistance to gonadotropic stimulations, resulting in low levels of estrogen, which cannot keep the normal endometrial growth [7].

In the present study, out of 60 cases of AUB, 23 were more than $36 \mathrm{yr}$ in age. In them bleeding disorders were more severe, their ET was $>8 \mathrm{~mm}$.

There is significant reduction in duration and severity of bleeding by hormonal treatment. Estrogen component stimulate uniform endometrial growth and promptly stops bleeding, while progesterone component stabilizes endometrium by converting it into pseudodecidua [4].

In our study, in younger age group showed significant response to hormonal treatment $80 \%$ cured by medical treatment only, while in premenopausal age group 50\% patient showed positive response to hormonal treatment. 
Machado L S et al in 2005 studied the correlation of ET, cycle day and histopathology in women with AUB. According to them no definite cut-off value could be assigned for the bleeding disorders in menstruating women [8].

Ozdemir S et al in 2009 studied Evaluation of ET with TVS and histopathology in premenopausal women with abnormal vaginal bleeding. This study included 144 premenopausal women with abnormal bleeding. In their observation they found 113 patients $(78.4 \%)$ had normal ET and 31 patients $(21.6 \%)$ had abnormal ET. They concluded that an endometrial biopsy or surgical $t / t$ was indicated when ET was $>8 \mathrm{~mm}[6]$.

Our study included 30 premenopausal women. We found that $26.7 \%$ patient showed normal ET ( $5-8 \mathrm{~mm}$ ), $43.3 \%$ showed moderate increase of ET $(8-11 \mathrm{~mm}) \&$ in $30 \%$ patient greater than $11 \mathrm{~mm}$ of ET was observed. Endometrial biopsy or surgical $\mathrm{t} / \mathrm{t}$ was indicated when ET was $>8 \mathrm{~mm}$.

In the Shaw's Textbook of Gynecology it is described that when no definitive cause is identified for polymenorrhea, $\mathrm{t} / \mathrm{t}$ with cyclical hormonal therapy restores the normal pattern of menstruation [9].

In our study, younger age group $87.5 \%$ patients responded to medical $\mathrm{t} / \mathrm{t}$, while in premenopausal age $\mathrm{gr}$ $46.2 \%$. Very few patients $23 \%$ patients of premenopausal age group required hysterectomy.

Medical line of treatment (antifibrinolytic agent, hormonal therapy) is effective in almost cases.30-40\% can be cured by $\mathrm{D} \& \mathrm{C}$ and very few may require hysterectomy [10].

In our study, medical treatment is effective in $33.3 \%$ cases. $43.4 \%$ were responded to D\&C (Dialatation \& curretage) \& $23.3 \%$ required further surgical treatment.

\section{Conclusion}

ET can be measured by USG- either transabdominally or transvaginally, which is the easiest and non invasive method. Its clinical importance and application extends throughout the phases of the reproductive life span of women.

AUB is one of the most common presenting complaints in women between menarche and menopause. The most common cause of abnormal vaginal bleeding is DUB. Majority of women with irregular and excessive bleeding have benign disorder, so instead of going for endometrial biopsy, ET can be a good screening tool. The present study emphasizes on the importance of ET in different age group, their response to medical line of $\mathrm{t} / \mathrm{t}$ and the role of ET in deciding the line of $\mathrm{t} / \mathrm{t}$.

We found that mean ET was in the normal range $(<8 \mathrm{~mm})$ in younger age group as compared to moderate ET $(8-11 \mathrm{~mm})$ in perimenopausal women. In perimenopausal age, the preferred line of treatment will be either D\&C or hysterectomy, when ET is $>8 \mathrm{~mm}$. In nutshell, in AUB- if ET is $<8 \mathrm{~mm}$, medical line of treatment is indicated. If ET is $>8 \mathrm{~mm}$ line of treatment depends on age and pattern of bleeding.

\section{Funding: Nil}

Conflict of interest: None initiated.

Permission from IRB: Yes

\section{References}

1. Williams PL, Worwick R; Gray' Anatomy .Splanchnology - urogenital system. $36^{\text {th }}$ edi. Churchill Livingstone Longman group Ltd. Edinburgh , UK 1980:1428

2. Datta DC. Text book of Gynecology. Menstuation. $2^{\text {nd }}$ edi. New central book agency Ltd. Calcutta, India 2000;75-90

3. Persadie RJ. Ultrasonographic assessment of endometrial thickness: a review. J Obstet Gynaecol Can. 2002 Feb;24(2):131-6

4. Delate OM, Gupta A, Abraham C, Chandrareddy A, Bowers Jr CH, Cutlet JB. Management of Dysfunctional Uterine Bleeding based on Endometrial Thickness. International Journal of Women's Health. 2010; 2: 297302

5. Dr. Chittacharoen A, Theppisai U, Linasmita V, Jittima M; Sonohysterography in the Diagnosis of Abnormal Uterine Bleeding. Journal of Obstetrics and Gynecology Research. Aug 2000 Aug; 26: 277-81

6. Ozdemir S, Cetin C, Gezginc K, Kiresi D, Esen H. Evaluation of endometrial thickness with transvaginal ultrasonography and histopathology in premenopausal women with abnormal vaginal bleeding. Journal of the International Gynecological Cancer Society.2009 Aug:19(6): 1085-90.

Available online at: www.ijmrr.in 266 | P a g e 
7. Dangle G; A study of endometrium of patients with abnormal uterine bleeding at Chitwan Valley. Katmandu University Medical Journal.2003; 1(2): 110-2

8. Machado LS, Mathew M, Al-Hassani A, Vaclavinkova V. Correlation of endometrial thickness, cycle day and histopathology in women with abnormal uterine bleeding. Saudi Med. J. 2005 Feb; 26( 2): 260-3.
9. Padubidri VG, Daftary SN; Shaw's Textbook of Gynecology. Disorder's of menstruation. $13^{\text {th }}$ edi. Elsevier, a division of Reed Elsevier India Private Limited, New Dehli 2006: 286

10. Padubidri VG, Daftary SN; Shaw's Textbook of Gynecology. Menorrhagia and Dysfunctional Uterine Bleeding. $13^{\text {th }}$ edi. . Elsevier, a division of Reed Elsevier India Private Limited, New Dehli 2006:296-297.

\section{How to cite this article?}

Shinde CD, Patil PG, Mane R. Endometrial thickness by USG as a guideline for the treatment of dysfunctional uterine bleeding in Premenopausal women. Int J Med Res Rev 2015;3(3):263-267. doi: 10.17511/ijmrr.2015.i3.048. 